\title{
Trace Gas Emission Data Bases for Atmospheric Chemistry Studies
}

\author{
Jane Dignon \\ Lawrence Livermore National Laboratory
}

October 7, 1991

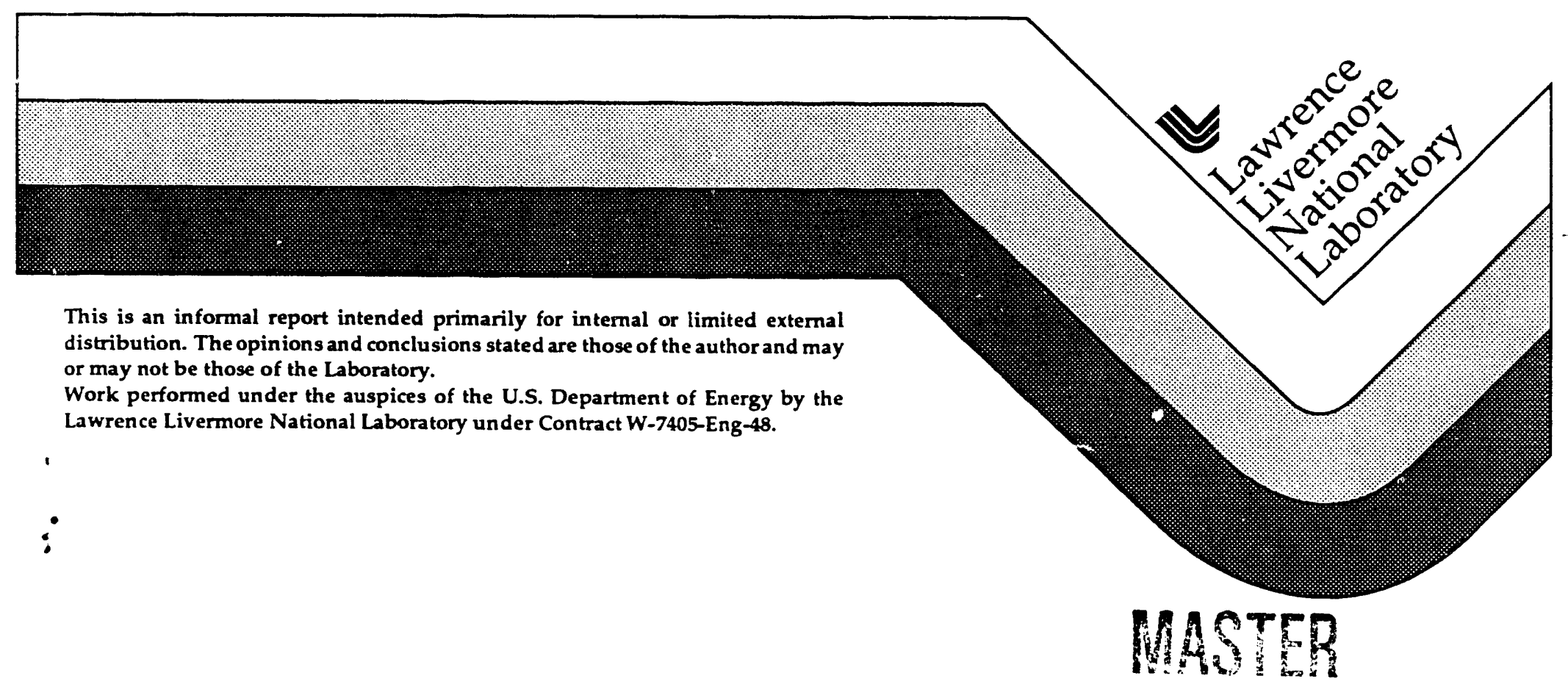




\section{DISCLAIMER}

This document was prepared as an acccount of work sponsored by an agency of the United States Government. Neither the United States Government nor the University of California nor any of their employees, makes any warranty, express or implied, or assumes any legal liability or responsibility for the accuracy, completeness, or usefulness of any information, apparatus, product, or process disclosed, or represents that its use would not infringe privately own rights. Reference herein to any specific commercial products, process, or service by trade name, trademark, manufacturer, or otherwise, does not necessarily constitute or imply its endorsement, recommendation, or favoring by the United States Government or the University of California. The views and opinions of authors expressed herein do not necessarily state or reflect those of the United States Government or the University of California, and shall not be used for advertising or product endorsement purposes.

This report has been reproduced directly from the best available copy.

Available to DOE and DOE contractors from the Office of Scientific and Technical Information P.O. Box 62, Oak Ridge, TN 37831

Prices available from (615) 576-8401, FTS 626-8401

Available to the public from the National Technical Information Service

U.S. Department of Commerce 5285 Port Royal Rd., Springfield, VA 2216 


\title{
Trace Gas Emission Data Bases for Atmospheric Chemistry Studies
}

\author{
Jane Dignon \\ University of California \\ Lawrence Livermore National Laboratory \\ UCRL-ID--108511 \\ DE92 002762
}

\section{Description}

Global data bases of trace gas emissions to the atmosphere have been compiled for the use in atmospheric chemistry studies. The resolution provided is a $1^{\circ}$ latitude by $1^{\circ}$ longitude based on previous work by Matthews (1983) and Matthews and Fung (1987). A series of 3 data bases has been provided. The first is an inventory of emissions of $\mathrm{NO}_{\boldsymbol{x}}$ from fossil fuel combustion, while the second is an inventory of $\mathrm{SO}_{2}$ emissions from the same anthropogenic source. An extensive description of these 2 data bases can be found in Dignon (1991). The third database includes a global inventory of the emissions of $\mathrm{NO}_{x}$ from terrestrial biomass burning and is given seasonally for the globe (Dignon and Penner, 1991; Dignon et al., 1991).

The units of emission for the inventories are given as the mass in metric tons of $\mathrm{N}$ for the $\mathrm{NO}_{x}$ inventories and metric tons of $\mathrm{S}$ for the $\mathrm{SO}_{2}$ inventory for each $1^{\circ} \times 1^{\circ}$ grid. The emissions are expected to represent the emissions for the year 1980. The biomass burning source is given for 2 seasons where $X X X X j$ jul represents an ascii file containing the cumulated emissions for the months from April to September, and XXXXjan represents October to March (Bates et al., 1991).

The grid for these data bases, $(\mathrm{i}, \mathrm{j})$ arrays, is $(360,180)$, which represents 1 degree (lon,lat) resolution. Here, $j=1,180$ and $j=1$ represents the latitude band 90 degrees south to 89 degrees, i.e. centered at 89.5 degrees south; $j=180$ represents the band from 89 degrees north to 90 degrees north, i.e. centered at 89.5 degrees north. Longitude is represented as $i=1,360$, where $i=1$ represents the band from 180 degrees (international date line) to 179 degrees west, i.e. centered at 179.5 degrees west; $i=360$ is the band from 179 degrees east to 180 degrees (date line), i.e. centered at 179.5 degrees east. The 
Figure. Data base array structure.

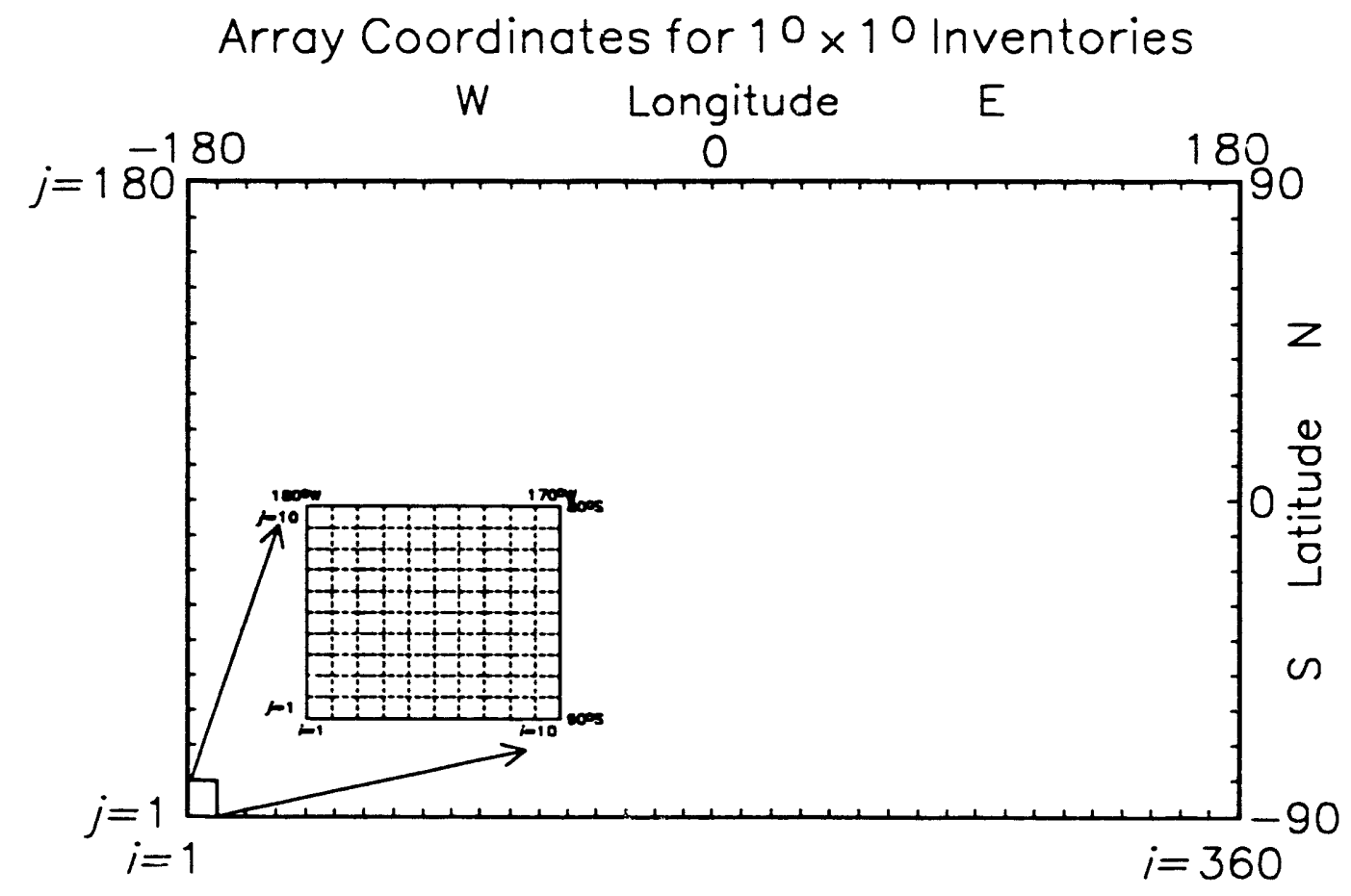

accompanying Figure illustrates the structure of the arrays.

The Table shows a description of each data base and provides FORTRAN code, documentaion, and data format for reading each array. Complete description of the emission inventory data bases can be obtained in the references listed below.

Acknowledgements: Work performed under the auspices of the U.S. Department of Energy by the Lawrence Livermore National Laboratory under contract No. W-7405-Eng48.

\section{References}

Bates, T.S., B.K. Lamb, A. Guenther, J. Dignon, and R.E. Stoiber, 1991. Sulfur emissions to the atmosphere from natural sources, Journal of Atmospheric Chemistry, in press. 
Dignon, J. 1991. $\mathrm{NO}_{x}$ and $\mathrm{SO}_{x}$ emissions from fossil fuels: A global distribution, Atmospheric Environment, in press.

Dignon, J. and J.E. Penner, 1991. Biomass burning: A source of nitrogen oxides in the atmosphere, Global Biomass Burning: Atmospheric, Climatic, and Biospheric Implications, ed. J.S. Levine, pp 370-375.

Dignon, J., C.S. Atherton, J.E. Penner, and J.J. Walton, 1991. $\mathrm{NO}_{x}$ pollution from biomass burning, submitted to the Proceedings of the 11 th COnference on Fire and Forest Meteorology, Missoula, MT, April 16-19, 1991. LLNL Report UCRL-JC-104735.

Matthews, E., 1983. Global vegetation and land use: New high-resolution data bases for climate studies, Journal of Climate and Applied Meteorology, 22, 474-487. 


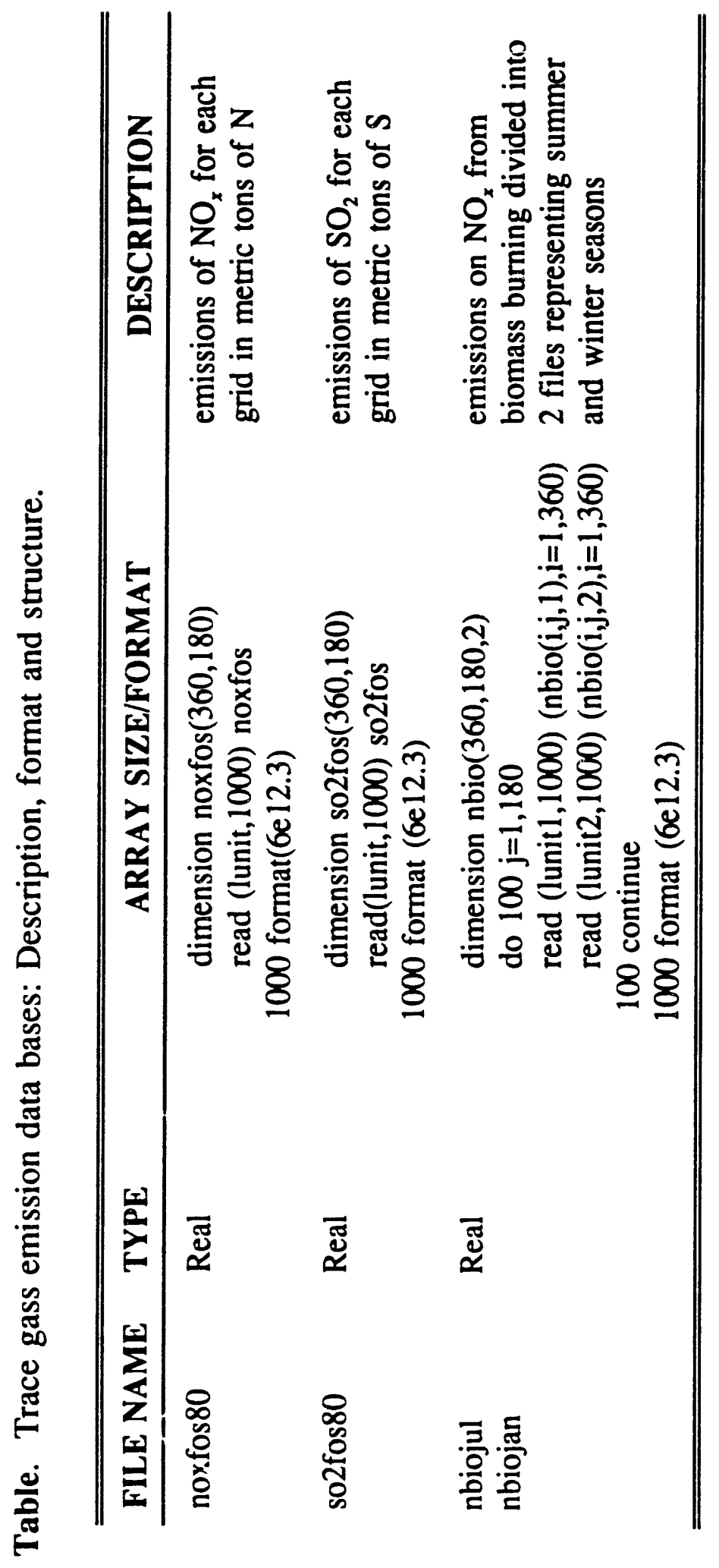



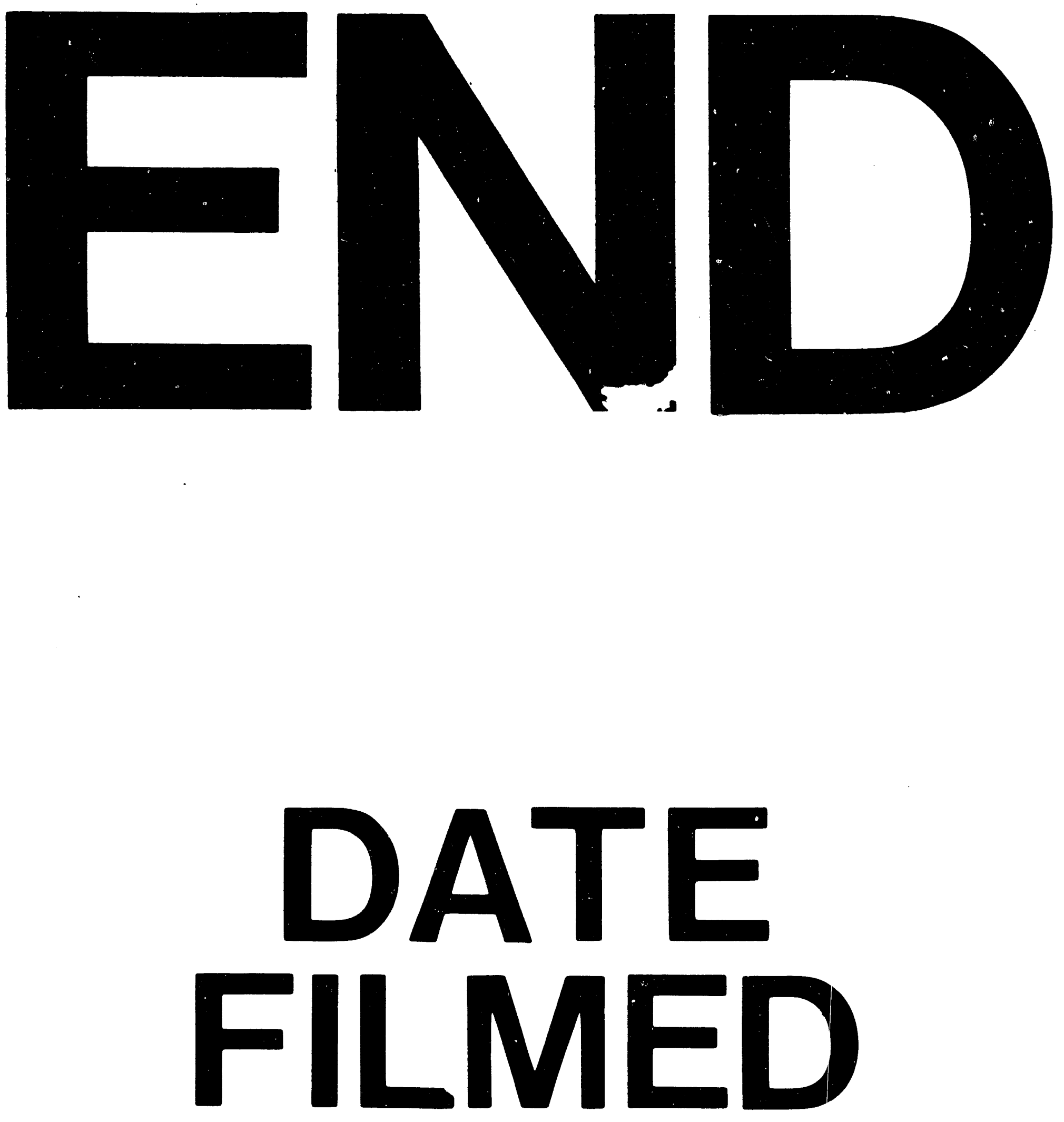

1

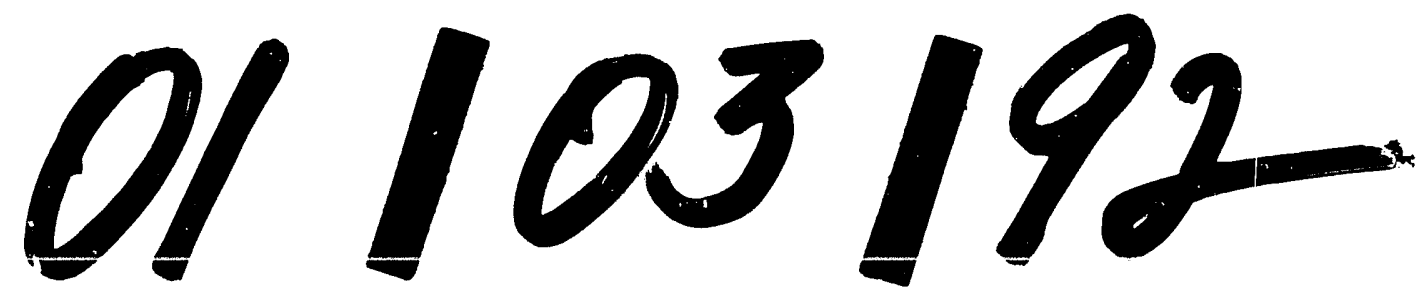




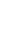

